\title{
The Role of Indonesia Virtual Police in Countering Hate Speech on Social Media
}

\author{
Adya Paramita Prabandari ${ }^{1}$, Irma Cahyaningtyas ${ }^{2}$, Kadek Cahya Susila Wibawa ${ }^{3}$ \\ \{apprabandari@gmail.com¹,irmafjr83@gmail.com², kadekwibawa@undip.ac.id ${ }^{3}$ \} \\ Universitas Diponegoro, Indonesia ${ }^{1,2,3}$
}

\begin{abstract}
The increase in the number of internet users and their activities in cyberspace, including using social media, on the other hand, is also followed by an increase in the emergence of the negative impact of the digital world such as the misuse of social media. The phenomenon of social media misuse that is increasingly widespread today is hate speech. This is then triggered the Indonesian National Police to launch the Virtual Police. This paper used a normative juridical method, using the statute approach, and the conceptual approach. The data used are secondary data obtained through library research. The widespread and fast-growing hate speech in social media can lead to open conflicts and national disintegration, if not addressed immediately. One effective way to combat the spread of hate speech, as well as to prevent the spread of hate speech, is to form a team of cyber police called the Virtual Police. The Virtual police play an incredibly important role in countering hate speech on social media, especially because the settlement used is a restorative justice approach.
\end{abstract}

Keywords: Role, Virtual Police, Counter, Hate Speech, Social Media

\section{Introduction}

The Three T Revolution (Transportation, Telecommunications, and Tourism) [1] resulted in very rapid and fundamental changes in the order of human life since the beginning of the $21^{\text {st }}$ century known as globalization. Since then, globalization has occupied a central point in various discussions in various fields, not limited to economics, transportation, and telecommunications.

One of the developments in the field of telecommunications that is very influential on people's lives is the existence of computers and the internet. The internet has 3 characters namely (1) space/time compression; (2) no sense of place; and (3) blurred boundaries and transformed communities [2][3]. The internet itself has changed a lot during these years. At first, it was a static network designed to transport a small number of bytes or short messages between two terminals; it was a repository of information where content is published and maintained only by expert coders. But today, a large amount of information is uploaded and downloaded through the internet, and the content is very much our own because now we are all commentators, publishers, and creators [4]. Along with the rapid development of the internet, a community in cyberspace is formed as a new type of global society, consisting of what is called net generation or digital natives [5][6][7]. Digital Natives is a generation that grew up primarily by the mass media and the internet, which was born after the 1980s, where the internet began to be widely used by the public. This generation is a generation that grows with the setting of information 
technology developments, especially mobile phones and the internet, which can bring the younger generation to roam the world in a virtual world without borders [8].

The digital natives as internet users have grown rapidly during the years, as shown in the graphic below [9].

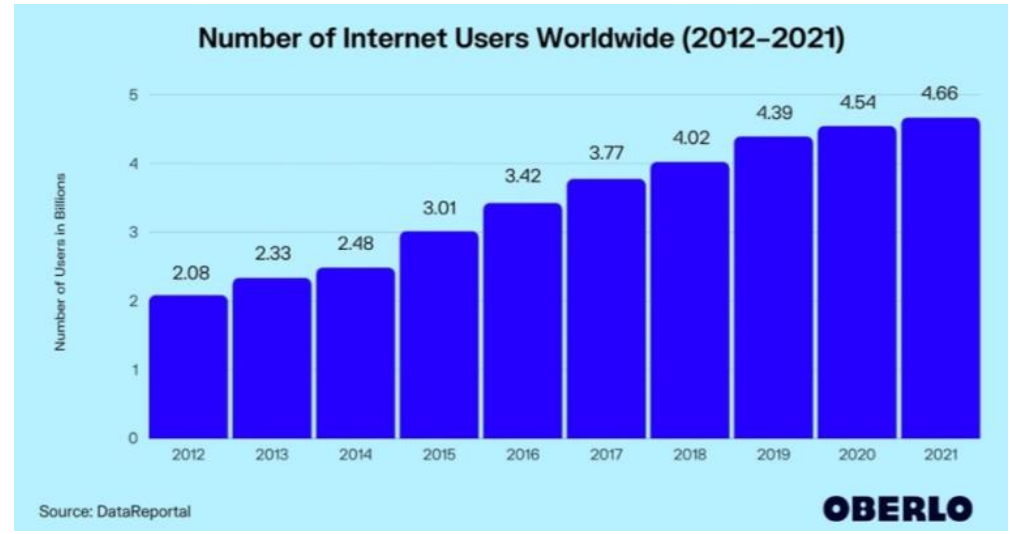

Graph 1. Number of Internet Users Worldwide (2012-2021).

From the graphic, we can see that the number of internet users worldwide has more than doubled in 2021 with 4.66 billion people, compared to the number of internet users worldwide in 2012. This shows that more and more people are using the internet for convenience and comfort in their daily lives.

The rapid growth of internet users globally, of course, also occurs in Indonesia. This can be seen from the graphic below [10].

\section{Internet Users \\ Indonesia, 2018-2022}

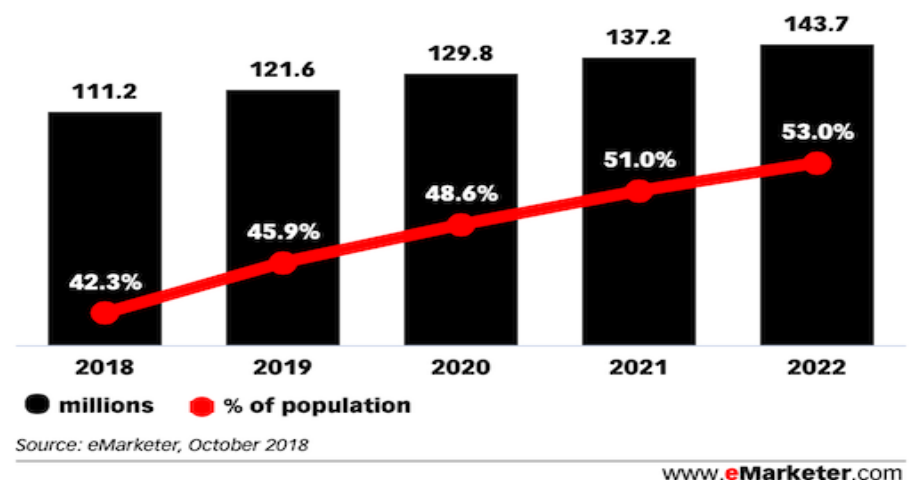

Graph 2. Internet Users. 
It can be seen that in only 3 years (2018-2021), the number of internet users in Indonesia has been increased by as much as 26 million people. Meanwhile, for the newest data, we can see the annual digital growth in Indonesia in the infographic below [11].

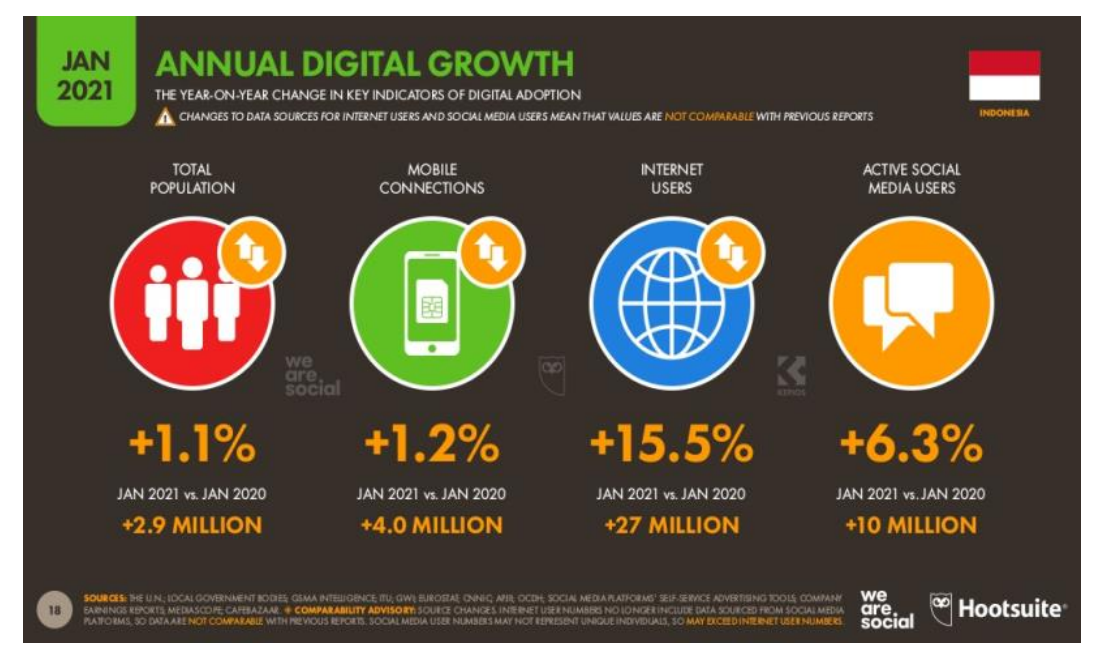

Graph 3. Annual Digital Growth.

The increase in the number of internet users and their activities in cyberspace, including in using social media. Social media now has become a vital part of the daily life of our society. If used wisely, social media can have positive impacts on its users and society as a whole. For example in terms of connectivity as in connecting family members and people around the world; in education; also in spreading information and updates throughout the world [12].

Nevertheless, the increasing use of social media is also followed by an increase in the emergence of the negative impacts of the digital world such as the misuse of social media. The misuse of social media can lead to, but is not limited to, sexual harassment; criminal misconduct; breach of work obligations; unlawful judgment; misconduct or violation of student, staff, or parent privacy; and exposure to legal obligations [13]. These things can take the form of child pornography, cyberbullying, and the widespread of hoaxes and hate speech [14].

The phenomenon of social media misuse that is increasingly widespread today is hate speech. Hate speech can be defined as "any kind of communication in speech, writing or behavior, that attacks or uses pejorative or discriminatory language with reference to a person or a group on the basis of who they are, in other words, based on their religion, ethnicity, nationality, race, color, descent, gender or other identity factors" [15]. This hate speech phenomenon appears partly due to the opinion of netizens that they can treat accounts on social media as their private space, and therefore are free to express anything without control. This is based on the reason that they have the freedom of speech [16]. In the beginning, the phenomenon of hate speech emerged when there were certain major events in Indonesia, such as political contestations during the general election. For example the widespread hate speech in the political contestation of the 2019 Presidential Election [17]. But lately, the phenomenon of hate speech often appears in everyday life and does not only occur during certain big moments [18]. For example is the fast-growing and spreading religious hate speech in social media, which if not immediately addressed can lead to openly sectarian violence (inter-religious conflict) and national disintegration [19]. The more hate speech is spreading on social media, of course, it 
raises concerns about conflicts and disintegration in society which will ultimately be very detrimental to the Indonesian nation. This is then triggered the Indonesian National Police to launch the Virtual Police on February 23, 2021.

From the description above, the purpose of this paper is to analyze the role of the Indonesian Virtual Police in countering hate speech on social media.

\section{Research Method}

The research method used in this paper is a normative juridical method, using 2 approaches namely the statute approach, and the conceptual approach. The data used are secondary data obtained through library research in the library and the internet. The data collected from the internet such as journal articles, online surveys, and news reports from various websites. The data is processed and analyzed using qualitative analysis methods and then presented in the form of systematic writing [20][21].

\section{Results and Discussion}

Social media is a term commonly used to refer to "new forms of media which involve interactive participation" [22]. Social media can be defined as "a group of Internet-based applications that build on the ideological and technological foundations of Web 2.0, and that allow the creation and exchange of user-generated content" [23]. There are 2 characteristics of social media i.e., 1) social media allow some form of participation; and 2) social media involve interaction whether with established friends, family, or acquaintances or with new people who share common interests or even a common acquaintance circle [22].

The emergence of social media in cyberspace has resulted in very radical and significant changes in the patterns and ways of communicating in society with its huge benefits, especially supported by the use of smartphone technology which can now be purchased by everyone with price ranges from cheap to very expensive [5].

However, the ease and convenience offered by the use of the internet and social media on the other hand also have negative impacts. One of them is the misuse of social media to spread hate speech. Hate speech is one form of aggressive behavior in an individual, or more precisely, an indirect active verbal aggression behavior [24]. The EU Community defines the concept of hate speech as "the expressions that incites, propagates, justifies the hatred which is usually associated with certain tribe, race, and religion". Some see hate speech as a form of intolerance to other people, and can be considered as "an expression that attacks and encourages violence" [25].

The cases of hate speech that occur in Indonesia are very diverse, including defamation, harassment, slander, provocation, and threats against individuals or groups, prohibition of worship for minority groups, and identity politics [26]. Hate speech has even become one of the serious problems in terms of using social media for the people of Indonesia. This condition then triggered the Indonesian National Police to issue the Chief of Police Circular Number $\mathrm{SE} / 6 / \mathrm{X} / 2015$ concerning the Handling of Hate Speech. Hate speech has also been regulated in the law as in Article 28 jis. Article 45 paragraph (2) of Law No. 11 of 2008 concerning Electronic Information and Transactions (EIT Law), and in Article 16 of Law No. 40 of 2008 
concerning the Elimination of Racial and Ethnic Discrimination. However, these actions did not succeed in reducing the spread of hate speech on social media.

The Indonesian National Police then launched the Virtual Police on February 23, 2021, with the Circular Letter of the Chief of Police Number SE/2/11/2021 on the Awareness of Ethical Culture to Create a Clean, Healthy, and Productive Indonesian Digital Space. The virtual police is a unit initiated by the National Police Chief General in response to President Joko Widodo's directive so that the Police are careful in applying the articles in the EIT Law [27]. In general, Virtual Police (sometimes called Internet Police or Cyber Police) can be defined as police or government agencies in charge of policing the internet, to fight all forms of cybercrimes.

The launching of Virtual Police aims to provide education to the public on social media about cases that can be charged under the EIT Law. In addition, the establishment of the Virtual Police is also an effort by the Police in creating public order security in the cyber world so that they move in a clean, healthy, and productive manner. Thus basically, the establishment of the Virtual Police is intended to hit negative content and hoaxes, as well as a means of public education related to the EIT Law.

As for the working procedures of the Virtual Police is as follows:

a. Asking for experts opinions on such content

- Virtual Police (cyber patrol team) conducts cyber patrol.

- If an upload is found to indicates violating the law (for example contains hate speech or hoax content), the findings will be notified to the headquarters to ask for opinions from experts (criminal experts, linguists, and EIT experts).

- If the expert says the content contains a criminal offense, whether insulting or otherwise, the next step is to submit it to the cyber director or a designated official in cybercrimes to provide approval.

- Thus the warning message will be given after considering expert opinions, not the subjective opinion of the National Police investigators.

b. First warning

- Virtual Police officially send the first warning message to accounts on social media that are suspected of violating the law.

- The warning will be sent via direct message (DM) or other personal media because the Police do not want the warning to be known by other parties. After all, it is confidential.

c. Second warning

If there is no response from the account owner to the first warning, the Police will send a second warning that the content must be taken down a maximum of $1 \times 24$ hours after the second warning is given.

d. Summoning for clarification

- If the upload is not deleted within 1x24 hours after sending the second warning, the account owner will be summoned for a clarification.

- The summons and clarification are closed from the public.

e. Prosecution as ultimum remedium

If the above process does not solve the problem, then further steps will be taken and the process of prosecution as the ultimum remidium.

From the working procedures of the Virtual Police aforementioned, it can be seen that in terms of virtual operation in countering hate speech content on social media, the Virtual Police use a restorative justice approach. The concept of the restorative justice approach focuses on the direct participation of perpetrators, victims, and the community in the process of resolving criminal cases. Restorative justice aims to empower victims, perpetrators, families, and 
communities to correct an unlawful act by using awareness and conviction as a basis for improving community life [28][29].

If the concept of restorative justice is applied by the Virtual Police in controlling and preventing the rise of hate speech and hoaxes, then the success of the Police in handling them is not seen from arresting suspects or obtaining evidence, but preventing crime by accommodating the interests of the perpetrators, the victims as the most disadvantaged parties, and the public interest. Because restorative justice prioritizes the creation of justice and balance between perpetrators and victims. Unless the hate speech content has the potential to be divisive, SARA, radicalism, and separatism can damage the unity and integrity of the Indonesian nation.

\section{Conclusion}

The widespread and fast-growing hate speech in social media can lead to open conflicts and national disintegration, if not addressed immediately. One effective way to combat the spread of hate speech, as well as to prevent the spread of hate speech, is to form a team of cyber police called the Virtual Police.

The Virtual Police play an incredibly important role in countering hate speech on social media, especially because the settlement used is a restorative justice approach. By using the restorative justice approach, it is expected that the settlement of the cases on hate speech contents in social media can create justice and balance between perpetrators and victims, unless the hate speech content has the potential to be divisive, SARA, radicalism, and separatism that can damage the unity and integrity of the Indonesian nation.

\section{References}

[1] R. N. Dwidjowijoto and M. P. Sumampow, Manajemen dalam Era Globalisasi. Jakarta: PT. Elex Media Komputindo, 1997.

[2] S. K. Tambyah, "Life on the Net: The Reconstruction of Self and Community," Advances in Consumer Research, vol. 23, pp. 172-177, 1996.

[3] R. Rettie, "Net Generation Culture," Journal of Electronic Commerce Research, vol. 3, no. 4, pp. 254-264, 2002.

[4] Z. Dentzel, "How the Internet Has Changed Everyday Life," in Change: 19 Key Essays on How the Internet Is Changing Our Lives, 2014. Accessed: Jun. 10, 2021. [Online]. Available: https://www.bbvaopenmind.com/en/articles/internet-changed-everyday-life/

[5] A. Prabandari, "Digital Natives and Freedom of Speech on Social Media in Indonesia," 2020.

[6] D. Tapscott, Growing Up Digital: The Rise of the Net Generation. New York: McGrwa-Hill, Inc., 1998.

[7] M. Akçayir, H. Dündar, and G. Akçayir, "What makes you a digital native? Is it enough to be born after 1980?" Computer in Human Behavior, vol. 60, pp. 435-440, 2016.

[8] R. Sugihartati, Perkembangan Masyarakat Informasi \& Teori Sosial Kontemporer, I. Jakarta: Kencana, 2014.

[9] Oberlo, "How Many People Use the Internet?" https://www.oberlo.com/statistics/how-manypeople-use-internet (accessed Jun. 10, 2021).

[10] C. Nguyen, "Indonesia Digital Landscape: 9 Key Facts," May 17, 2019. https://www.chandlernguyen.com/blog/2019/05/17/indonesia-digital-landscape-what-youneed-to-know/ (accessed Jun. 10, 2021).

[11] S. Kemp, "Digital 2021: Indonesia," Feb. 11, 2021. https://datareportal.com/reports/digital2021-indonesia (accessed Jun. 10, 2021). 
[12] W. Akram and R. Kumar, "A Study on Positive and Negative Effects of Social Media on Society," International Journal of Computer Sciences and Engineering, vol. 5, no. 10, pp. 351354, 2017.

[13] Krisna, "Social Media Misuse Consequences You Need to Know," 2021. https://www.digitalnuisance.com/social-media-misuse/ (accessed Aug. 01, 2021).

[14] A. Rahmadhany, A. Aldila Safitri, and I. Irwansyah, "Fenomena Penyebaran Hoax dan Hate Speech pada Media Sosial,” Jurnal Teknologi Dan Sistem Informasi Bisnis, vol. 3, no. 1, pp. 30 43, 2021

[15] “United Nations Strategy and Plan of Action of Hate Speech.” Accessed: Jun. 10, 2021. [Online]. Available:

https://www.un.org/en/genocideprevention/documents/UN\%20Strategy\%20and\%20Plan\%20of $\% 20$ Action\%20on\%20Hate\%20Speech\%2018\%20June\%20SYNOPSIS.pdf

[16] D. M. Herawati, "Penyebaran Hoax dan Hate Speech sebagai Representasi Kebebasan Berpendapat," Jurnal Promedia, vol. 2, no. 2, 2016.

[17] P. Fajriyah, "Virtual Democracy Studi Pada Pola Komunikasi Politik Hate Speech dan Hoax Pilpres 2019 Melalui Media Sosial," Interaktif: Jurnal Ilmu-Ilmu Sosial, vol. 11, no. 1, pp. 22 49, 2019.

[18] M. Beryandhi, "Media Baru dan Fenomena Hate Speech di Indonesia: Media Penyakit Sosial Baru," Oct. 27, 2020. https://kumparan.com/mohamad-beryandhi/media-baru-dan-fenomenahate-speech-di-indonesia-media-penyakit-sosial-baru-1uTKOats1y9/full (accessed Jun. 10, 2021).

[19] Muhyiddin, "8 Modus Ujaran Kebencian yang Bisa Picu Konflik Beragama." Accessed: Aug. 01, 2021. [Online]. Available: https://www.republika.co.id/berita/pwjtzx320/8-modus-ujarankebencian-yang-bisa-picu-konflik-beragama

[20] R. H. Soemitro, Metodologi Penelitian Hukum dan Jurimetri. Jakarta: Ghalia Indonesia, 1990.

[21] J. Ibrahim, Teori \& Metodologi Penelitian Hukum Normatif. Malang: Bayumedia Publishing, 2006.

[22] J. Manning, "Social Media, Definition and Classes of," Encyclopedia of Social Media and Politics. Sage, Thousand Oaks, CA, pp. 1158-1162, 2014. Accessed: Jun. 10, 2021. [Online]. Available: https://www.researchgate.net/publication/290514612

[23] A. M. Kaplan and M. Haenlein, "Users of the world, unite! The challenges and opportunities of Social Media," Business Horizons, vol. 53, no. 1, pp. 59-68, 2010.

[24] A. Rahmadhany, A. Aldila Safitri, and I. Irwansyah, "Fenomena Penyebaran Hoax dan Hate Speech pada Media Sosial," Jurnal Teknologi dan Sistem Informasi Bisnis, vol. 3, no. 1, Jan. 2021.

[25] S. Widodo, "Digital Literacy as Strategy Responding to Hate Speech in Social Media," Apr. 12, 2017. http://news.unair.ac.id/en/2017/04/12/digital-literacy-strategy-responding-hate-speechsocial-media/ (accessed Jun. 10, 2021).

[26] Irawan, "Hate Speech di Indonesia: Bahaya dan Solusi," Jurnal Dakwah dan Pengembangan Sosial Kemanusiaan, vol. 9, no. 1, pp. 1-17, Jun. 2018.

[27] T. Maharani, "Mengenal Virtual Police: Definisi, Dasar Hukum, hingga Polemiknya," Mar. 17, 2021. https://nasional.kompas.com/read/2021/03/17/14414171/mengenal-virtual-policedefinisi-dasar-hukum-hingga-polemiknya?page=all (accessed Jun. 10, 2021).

[28] D. S. Dewi and F. A. Syukur, Mediasi Penal: Penerapan Restorative Justice di Pengadilan Anak Indonesia. Depok: Indie Publishing, 2011.

[29] J. Mareta, "Penerapan Restorative Justice melalui Pemenuhan Restitusi pada Korban Tindak Pidana Anak," Jurnal Legislasi Indonesia, vol. 15, no. 4, pp. 309-319, 2018. 